\title{
The Impact of Pipe Distribution Network on the Quality of Tap Water in Ojota, Lagos State, Nigeria
}

\author{
Odafivwotu Ohwo* \\ Department of Geography and Environmental Management, Faculty of Social Sciences, Niger Delta University, Wilberforce Island, \\ Bayelsa State, Nigeria \\ *Corresponding author: drohwodafe@gmail.com
}

Received September 24, 2014; Revised October 08, 2014; Accepted October 16, 2014

\begin{abstract}
Public water supply is distributed through water pipe network, which may affect the quality of water that gets to the consumers if the integrity of the pipe distribution network is compromised. Hence, this study was designed to determine whether there is significant variation in the water quality that gets to the consumer after transportation through the pipe distribution network. In order to achieve this aim, twenty-five tap water samples were randomly collected. In addition, a control sample was collected from Iju Water Works, which serve Ojota community. The analyses revealed that the measured values of some of the selected tap water quality parameters varied from Iju Water Works, to the various sampled zones. For example, total coliform and fecal coliform bacteria counts show that 8 (30.72\%) and 6 (23.08\%) samples have concentrations above the WHO zero thresholds for total and fecal coliform, respectively. In addition, turbidity and color show unsatisfactory concentrations in some of the sampled tap water, as turbidity has 17 (65.38\%) of the samples having concentration above the 5 NTU WHO threshold for drinking water; while all the 25 (100\%) tap water samples, have color values above the WHO 5 unit threshold. Similarly, the values of residual chlorine vary from $0.5 \mathrm{mg} / \mathrm{l}$ at Iju Water Works, to $0-0.25 \mathrm{mg} / \mathrm{l}$ at the various zones. The T-test analyses revealed that there are significant differences between the quality values at Iju Water Works and the various zones. This is an indication that the integrity of the treated water transported to Ojota has been compromised and not safe for human consumption. It is recommended that the Lagos State Government should undertake a general overhaul and replacement of the dilapidated water pipe distribution network in the state to guarantee safe supply of tap water to the populace.
\end{abstract}

Keywords: distribution network, Ojota, quality variation, tap water, WHO thresholds

Cite This Article: Odafivwotu Ohwo, “The Impact of Pipe Distribution Network on the Quality of Tap Water in Ojota, Lagos State, Nigeria.” American Journal of Water Resources, vol. 2, no. 5 (2014): 110-117. doi: 10.12691/ajwr-2-5-2.

\section{Introduction}

Safe drinking water and basic sanitation are extremely important to the preservation of human health, especially among children. Water-related diseases are the most common cause of illness and death among the poor of developing countries [1]. The World Health Organization (WHO) has observed that about 80 percent of diseases in the world are water related. Currently, about $20 \%$ of the world's population lacks access to safe drinking water and more than 5 million people die annually from illness associated with safe drinking water or inadequate sanitation. If everyone had safe drinking water and adequate sanitation services, there would be 200 million fewer cases of diarrhea and 2.1 million fewer deaths caused by diarrhea illness each year [2]. In addition to these 'direct health' effects of inadequate water supply provision, there is an additional cost in time and energy expended in carrying water from the supply to the family dwelling.
Improving water supplies has been a high priority activity for most developing country governments, donor agencies and communities for many years now so as to achieve the Millennium Development Goal 7 target 10 (halving by 2015, the proportion of people without sustainable access to safe water and basic sanitation), with the reference year of 1990. In order to achieve this goal, the federal and the state governments of Nigeria have step up efforts in expanding the various water corporations' distribution networks, which are charged with the responsibilities of delivery potable water to the populace. In spite of these recent efforts, water and sanitation coverage rates in Nigeria are among the lowest in the world. According to WHO/UNICEF [3] drinking water coverage in Nigeria fell from 49 percent in 1990 to 48 percent in 2004 as against the expected 65 percent coverage.

In spite of this unfortunate situation, a large number of those with access to the public water systems in Nigeria are not completely free from water borne diseases, because the quality of the water that eventually get to the consumers may not be guaranteed. A distribution system's pipes and storage facilities constitute a complex network 
of uncontrolled physical, chemical, and biological reactors that can produce significant variations in water quality. Although protected water sources and modern, wellmaintained drinking water treatment plants can provide water adequate for human consumption; ageing, stressed or poorly maintained distribution systems can cause the quality of piped drinking water to deteriorate below acceptable levels and pose serious health risks to its consumers [4].

Biofilms, which are coatings of organic and inorganic materials in water pipe distribution systems, has generated health concerns because they harbor, protect and allow the proliferation of several bacteria pathogens, including legionella and mycobacterium avium complex (MAC). Bacteria growth in biofilms is affected by several factors, including water temperature, type of disinfectant and residual concentration, biodegradable organic carbon level, degree of pipe corrosion and treatment/distribution system characteristics. Hence, [5] noted that the water quality of a drinking water system might be acceptable when the water leaves a treatment plant. However, a variety of physical, chemical, and biological transformations can happen once the water enters and travels through a distribution system, which can result to objectionable taste and odour and the risk of gastrointestinal illnesses. This situation was confirmed by [6] who reported that micro organisms in municipal drinking water supplies have led to several outbreaks of water-borne diseases in the United States. For instance, cryptosporidium in Milwaukee's water supply resulted in some 400, 000 serious illnesses and 50 deaths in the spring of 1993. In 1983, contaminated drinking water in Luzerne County, Pennsylvania caused an outbreak of giardiasis-a common diarrhea that left 6 , 000 people ill and forced 75, 000 others to obtain more expensive alternative sources of drinking water.

The integrity of water distribution networks in Nigeria and in particular in Lagos State is highly questionable, as it is characterized with leaky pipe joints, pipe breaks, corrosive pipes, intermittent supply, etc which may impact negatively on water quality through contamination before it gets to the consumer. But unfortunately, most people used to assume that if water entering into a distribution system were of high quality, its quality would still be good at the tap [7]. Therefore, people consume tap water without any doubt of its quality. This situation can be very dangerous if actually the quality of water that gets to the consumer has been compromised.

Little research is being conducted towards determining whether distribution system inadequacies are a result of sporadic breakdowns or are continually occurring. Moreover, very few epidemiological studies have been published on disease outbreaks in relation to distribution network deficiencies in developing countries. Hence there is a vital need for further research on drinking water distribution systems in developing countries [4]. Therefore, this study was aimed at the determination of the quality of tap water that has been transported through the distribution network to the consumer. This would enable us to know whether the water quality that gets to the consumer has varied significantly and its characteristics remain safe for human consumption.

\section{Method of Study}

This study involves the sampling of 25 tap water samples, which were collected at designated points adequately distributed throughout Ojota (headquarters of Kosofe Local Government Area of Lagos State). In order to avoid bias sampling of the tap water samples, Ojota was classified into five zones, namely: Ojota East, Ojota West, Ojota Central, Ojota South, and Ojota North. This classification gives an even representation of all segments of the population. The 25 tap water samples were randomly collected from these zones, which represent 5 tap water samples from each zone. In addition, a control sample was collected from Iju Water Works, which serve Ojota and other communities. This was done to determine whether there is variation in the quality of the treated water after being transported through the pipe distribution networks to the various zones.

Before the tap water samples were collected, cotton wool soaked in 70 percent ethanol was used to sterilize the nozzle of the tap and was allowed to run for about two to three minutes. The water samples were then collected with the aid of 25 one-liter plastic cans after thorough washing and rinsing with the respective water samples. Samples for microbial analysis were kept with a sterilized capped bottle to arrest the further growth of bacterial prior to analysis. After collection, the water samples were dully labeled kept in a cooler box containing ice and were immediately sent to the laboratory for analysis using standard methods [8]. Similar methods were adopted by [9] and they achieved significant results.

The collected water samples were analyzed for their physical, chemical and bacteriological characteristics. The quality parameters that were analyzed included turbidity, total dissolved solids, total suspended solids, $\mathrm{pH}$, electrical conductivity, color, lead, copper, magnesium, iron, calcium, zinc, cadmium, residual chlorine, phosphate, nitrate, fluoride, and total coliform and fecal coliform bacteria counts.

Unstable $\mathrm{pH}$ parameter was measured in-situ, with an ATI-Orion $\mathrm{pH}$ meter; while turbidity, TDS and TSS were respectively measured with a 214 A turbidity meter, conductivity and photometric methods. Total coliform counts were determined by the most probable number method (MPN/100ml). The numbers of confirmed coliform per $100 \mathrm{ml}$ were estimated from the MPN table. The Perkin Elmer 3110 Atomic Absorption Spectrophotometer (AAS) was used to determine heavy metal concentrations in the sampled tap water, with the appropriate wave length for each of the metals. The data were analyzed with the aid of descriptive statistics and T-test (E- view 7.0 package) (which determines whether there is significant difference between the measured values of the control sample at Iju Water Works and each of the stratified zones); while the quality of the water samples were compared with the WHO thresholds for drinking water supply.

\section{Results and Discussion}

\subsection{Biological Parameters}

3.1.1. Total Coliform and Fecal Coliform Bacteria Counts 
The biological characteristics of the tap water were determined based on total coliform and fecal coliform bacteria counts. The analysis of total coliform counts is widely used as an indication of the presence or absence of pathogenic bacteria in drinking water supply. The absence of total coliform counts in drinking water is regarded as a guarantee of freedom from pathogenic bacteria [10]. The values of total coliform counts of the sampled water at the various zones (Table 1) indicated that some of the tap water samples are contaminated, as the measured values ranges from 0 to $6 \mathrm{MPN} / 100 \mathrm{ml}$. The highest value of 6 MPN/100ml was measured at Ojota Central (sample 11), which is $600 \%$ higher than the zero threshold of the WHO for drinking water. There were 8 (30.77\%) of the tap water samples where total coliform counts were detected, with values ranging from 2.0 to $6.0 \mathrm{MPN} / 100 \mathrm{ml}$. Pathogens of fecal origin were isolated in 6 (23.08\%) tap water samples, with values ranging from 0.4 to1.5. The highest value was recorded at Ojota West (sample 7), where 1.5 MPN/100ml fecal coliform was recorded. At Iju Water Works (control sample) no coliform count was measured, which indicated that the pathogens got into the water while being transported through the pipe distribution network. During the fieldwork it was observed that some of the pipes have leaky joints, broken valves and are laid on poorly drained gutters, which provide easy access of pathogens into the pipe distribution network through back-siphonage. These problems coupled with intermittent water supply, low pressure, and corrosion of pipe materials help to degrade the quality of the tap water before it gets to the consumer. It is therefore not surprising that water borne diseases are a common health challenge in Lagos State.

Table 1. Biological Characteristics of Sampled Tap Water in Ojota

\begin{tabular}{|c|c|c|}
\hline Zone/Sample & Total coliform counts & Fecal coliform counts \\
\hline Ojota east 1 & 0 & 0 \\
\hline Ojota east 2 & 0 & 0 \\
\hline Ojota east 3 & 0 & 0 \\
\hline Ojota east 4 & 0 & 0 \\
\hline Ojota east 5 & 5.0 & 1.2 \\
\hline Ojota west 6 & 4.5 & 0.8 \\
\hline Ojota west 7 & 5.0 & 1.5 \\
\hline Ojota west 8 & 0 & 0 \\
\hline Ojota west 9 & 0 & 0 \\
\hline Ojota west 10 & 3.5 & 0.5 \\
\hline Ojota central 11 & 6.0 & 1.2 \\
\hline Ojota central 12 & 0 & 0 \\
\hline Ojota central 13 & 0 & 0 \\
\hline Ojota central 14 & 2.6 & 0 \\
\hline Ojota central 15 & 0 & 0 \\
\hline Ojota south 16 & 0 & 0 \\
\hline Ojota south 17 & 3.0 & 0.4 \\
\hline Ojota south 18 & 0 & 0 \\
\hline Ojota south 19 & 0 & 0 \\
\hline Ojota south 20 & 0 & 0 \\
\hline Ojota north 21 & 2.0 & 0 \\
\hline Ojota north 22 & 0 & 0 \\
\hline Ojota north 23 & 0 & 0 \\
\hline Ojota north 24 & 0 & 0 \\
\hline Ojota north 25 & 0 & 0 \\
\hline $\begin{array}{l}\text { Iju water works } \\
\text { (control sample) } 26\end{array}$ & 0 & 0 \\
\hline Range & 6.0 & 1.5 \\
\hline Mean & 1.22 & 0.22 \\
\hline Standard deviation & 2.00 & 0.45 \\
\hline $\begin{array}{ll}\text { Coefficient } & \text { of } \\
\text { variation (\%) } & \\
\end{array}$ & 163.9 & 204.5 \\
\hline
\end{tabular}

Source: Author's fieldwork, 2013

Similar studies have also shown that distribution networks contribute to the deterioration of water quality.
For example, Basualdo et al [11] in their study in La Plata, Argentina, detected intestinal parasites in tap water samples from four regional zones, but no parasites were detected from samples taken in the immediate vicinity of the plant. In the same vein, [12] also detected pathogenic bacteria in 8 out of the 18 sampled tap water in Lagos State, Nigeria. Specifically, they isolated Escherichia coli and klebsiella pnenumoniae. Similarly, Gaytan et al [13] reported that in Mexico City, bacteriological contamination increased by $26 \%$ from the point of treatment to the consumer's tap. Also, in a Trinidadan community, Agard et al [14] reported that $80 \%$ of household tap water samples tested positive for total coliforms, while no samples from the treated reservoir tested positive.

Some epidemiological studies have also established associations between declining water quality from distribution systems and increased risk of gastrointestinal illness [4]. For example, in Dushanbe, Tajikistan, fecal contamination of water occurred after treatment via the distribution system, leading to an outbreak of typhoid fever in the community [15]. Similarly, in Nukus, Uzbekistan, low pressure within the distribution system preceded an outbreak of diarrhea [16]. These findings show clearly that the inhabitants of Ojota are exposed to pathogenic diseases, since tap water is perceived as safe for human consumption without further treatment. Figure 1 shows the mean variation of total coliform and fecal coliform counts of tap water at Iju Water Works (control sample) and the sampled zones.

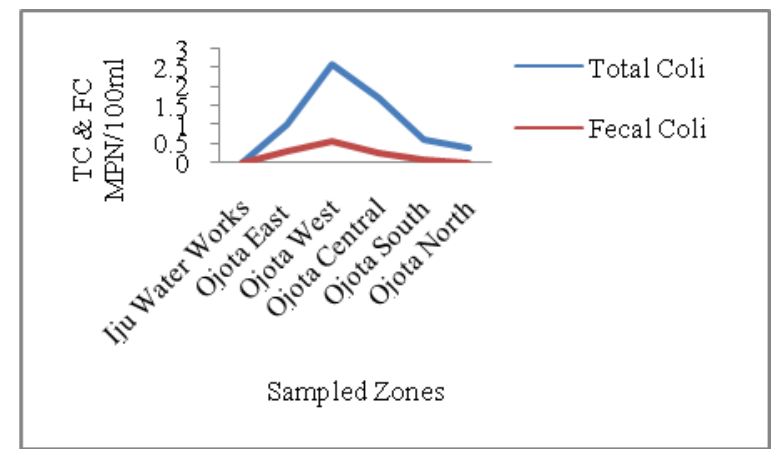

Figure 1. Mean Variation of Total Coliform and Fecal Coliform Counts of Tap Water in the Sampled Zones

\subsection{Physical Parameters}

\subsubsection{Turbidity, Color, TSS, TDS, $\mathrm{pH}$ and Electrical Conductivity}

Turbidity is the interference of light passage through water by insoluble particles. It is used as an indicator to determine water quality and often, filtration effectiveness $[17,18]$. Turbidity is known to interfere with disinfection and provide a medium for microbial growth [10]. High turbidity may also be an indication of the presents of disease causing organisms such as bacteria, viruses and parasites that could cause symptoms such as nausea, cramps and diarrhea. This probably informed the 5 NTU thresholds for turbidity concentration in potable water supply by the World Health Organization (WHO). From Table 2, it is revealed that turbidity concentration in the sampled tap water in the various zones ranged from 1.07 to 10.03 NTU. The lowest value of 1.07 , which is $78.6 \%$ below the 5 NTU WHO thresholds was recorded at Iju 
Water Works (control sample), while the highest value of 10.3 NTU, which is $106 \%$ above the WHO 5 NTU thresholds was recorded at Ojota Central (sample 11). 17 (65.38\%) samples have turbidity values above the WHO 5 NTU thresholds, with only 9 (34.62\%) samples below the threshold. This is an indication that the water in the affected zones may not be safe for human consumption without adequate treatment for turbidity. The turbidity range is an indication that there is a variation in the value of turbidity concentration in the sampled water from Iju Water Works (control sample) to the various zones after the water had traveled through the pipe distribution networks. The standard deviation and coefficient of variation of turbidity concentration in the sampled water are 2.31 and $37.56 \%$ respectively.

Table 2. Physical Characteristics of Sampled Tap Water in Ojota

\begin{tabular}{|c|c|c|c|c|c|c|}
\hline Zone/Sample & Turb. NTU & TSS Mg/l & TDS Mg/l & $\mathrm{PH}$ & $\mathrm{EC} \mu \mathrm{s} / \mathrm{cm}$ & Color TCU \\
\hline Ojota east 1 & 6.80 & 0 & 70.2 & 6.7 & 105.2 & 6.18 \\
\hline Ojota east 2 & 5.01 & 0 & 69.0 & 6.5. & 87.0 & 6.80 \\
\hline Ojota east 3 & 4.60 & 0 & 64.5 & 6.8 & 102.0 & 6.83 \\
\hline Ojota east 4 & 3.50 & 0 & 75.0 & 6.5 & 95.3 & 5.42 \\
\hline Ojota east 5 & 10.02 & 1.0 & 50.5 & 6.7 & 96.0 & 15.10 \\
\hline Ojota west 6 & 8.07 & 0 & 65.5 & 7.3 & 99.1 & 7.90 \\
\hline Ojota west 7 & 9.00 & 0.05 & 58.0 & 7.1 & 93.8 & 15.20 \\
\hline Ojota west 8 & 4.95 & 0 & 60.0 & 6.9 & 102.5 & 7.00 \\
\hline Ojota west 9 & 6.00 & 0 & 64.1 & 7.3 & 98.3 & 7.45 \\
\hline Ojota west 10 & 7.50 & 0 & 61.4 & 7.2 & 94.7 & 9.60 \\
\hline Ojota central 11 & 10.03 & 1.05 & 65.7 & 7.0 & 96.8 & 16.50 \\
\hline Ojota central 12 & 4.00 & 0.20 & 65.0 & 6.6 & 103.4 & 8.50 \\
\hline Ojota central 13 & 3.50 & 0.15 & 67.8 & 7.2 & 87.9 & 6.00 \\
\hline Ojota central 14 & 8.00 & 0.80 & 54.7 & 6.8 & 110.0 & 5.68 \\
\hline Ojota central 15 & 7.00 & 0 & 55.8 & 7.1 & 89.0 & 7.40 \\
\hline Ojota south 16 & 5.20 & 0 & 63.5 & 6.8 & 94.8 & 6.00 \\
\hline Ojota south 17 & 10.00 & 2.00 & 70.4 & 6.5 & 78.0 & 15.50 \\
\hline Ojota south 18 & 5.50 & 0 & 64.3 & 6.8 & 85.6 & 8.00 \\
\hline Ojota south 19 & 4.45 & 0 & 58.2 & 7.2 & 115.0 & 7.65 \\
\hline Ojota south 20 & 6.50 & 0 & 49.0 & 6.7 & 88.6 & 8.30 \\
\hline Ojota north 21 & 8.02 & 0 & 65.1 & 7.2 & 96.3 & 7.02 \\
\hline Ojota north 22 & 3.80 & 0 & 62.0 & 6.4 & 101.3 & 5.64 \\
\hline Ojota north 23 & 7.40 & 0.10 & 71.2 & 6.7 & 73.9 & $6-90$ \\
\hline Ojota north 24 & 6.20 & 0 & 56.3 & 6.2 & 86.5 & 7.54 \\
\hline Ojota north 25 & 3.75 & 0 & 67.8 & 6.2 & 93.7 & 6.45 \\
\hline $\begin{array}{l}\text { Iju water works } \\
\text { (control) } 26\end{array}$ & 1.07 & 0 & 43.0 & 7.4 & 63.5 & 4.90 \\
\hline Range & 8.96 & 2.00 & 32.0 & 1.2 & 51.5 & 11.6 \\
\hline Mean & 6.15 & 0.21 & 62.23 & 6.8 & 93.78 & 8.29 \\
\hline Standard deviation & 2.31 & 0.47 & 7.39 & 0.34 & 10.99 & 3.34 \\
\hline Coefficient of variation (\%) & 37.56 & 223.81 & 11.88 & 5.0 & 11.72 & 40.29 \\
\hline
\end{tabular}

Source: Author’s fieldwork, 2013.

One of the probably reasons for the high concentration of turbidity in the sampled tap water is the disruption of production at the water works. This leads to dryness of the pipes and when production is restored the accumulated sediments, which are usually found in pipe distribution systems, but remain within as a result of continuous production, is pushed out by the water head. This makes the water to be muddy and highly turbid. Another major probable cause of turbidity in the tap water is the corrosion of the pipe distribution network. This view was also held by [19] who stated that corrosion increases the amount of precipitates in water, which increases the amount of particulate matter (and thus turbidity). This situation can create a favorable environment for microbes; which may attach and aggregate onto these particulates and be protected from disinfection [20], rendering a disinfection residual less effective.

The values of color follow a similar trend with turbidity values. The turbid nature of the water also impacts on its color as the values ranges from 4.90 to 16.5 TCU (Table 2). The lowest color value was recorded at Iju Water Works (control sample), while the highest value was recorded at Ojota Central (sample 11), which equally has the highest turbidity value of 10.03 NTU. All the samples except the control sample have color values above the 5 unit of WHO threshold. The standard deviation and coefficient of variation of 3.34 and $40.29 \%$ show that there exist color variations in the tap water from Iju Water Works to the various zones in Ojota. The color variation may be attributable to corrosion of the pipe materials, intermittent production and pipe breakages, which result in backsiphoning of water into the pipe distribution network, which can affect the water color depending on the type of materials that are introduced into the network. This claim is supported by [21] who opined that a drop or differential in pipeline pressure could result in the reversal of flow, with water flow in the direction of lower pressure. As a result backflow occurs, which is defined as the flow of undesirable water back into the potable drinking water supply.

The measured values of TSS range from 0 to 2.0. Total Suspended Solids was not detected in 18 (69.23\%) of the 
sampled tap water at the various zones and at Iju Water Works (control sample) as indicated in Table 2. Although 8 (30.77\%) samples have TSS concentration, however, all the measured values are within the WHO $5 \mathrm{mg} / \mathrm{l}$ threshold for drinking water. Figure 2 shows the mean variation of turbidity, total suspended solids and color of tap water at Iju Water Works (control sample) and the sampled zones.

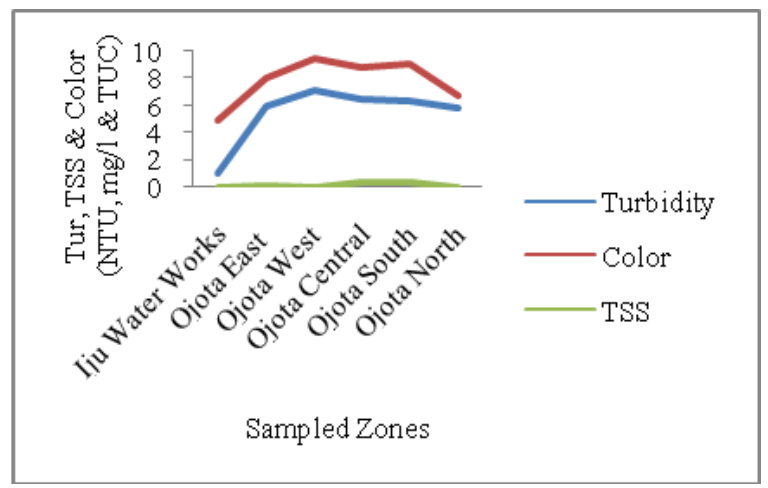

Figure 2. Mean Variation of Turbidity, Color and TSS of Tap Water in the Sampled Zones

TDS values range from 43.0 to $75.0 \mathrm{mg} / \mathrm{l}$ (Table 2). The lowest value of $43.0 \mathrm{mg} / \mathrm{l}$ was recorded at Iju Water Works (control sample), which is $91.4 \%$ below the 500 $\mathrm{mg} / \mathrm{l}$ WHO thresholds; while the highest TDS value of $75.0 \mathrm{mg} / \mathrm{l}$, which is $85 \%$ below the $500 \mathrm{mg} / \mathrm{l} \mathrm{WHO}$ thresholds, was measured at Ojota East (sample 4). The standard deviation of TDS was 7.39, while the coefficient of variation was $11.88 \%$, which indicate variations in the concentration of TDS in the sampled water at the various zones, after transportation through the pipe distribution networks. However, all the concentrations are within the acceptable $500 \mathrm{mg} / \mathrm{l}$ WHO thresholds. Electrical Conductivity values show concentrations that are within the acceptable $1000 \mu \mathrm{s} / \mathrm{cm}$ WHO thresholds with values ranging from 63.5 to $115 \mu \mathrm{s} / \mathrm{cm}$. The lowest value of $63.5 \mu \mathrm{s} / \mathrm{cm}$ was recorded at Iju Water Works (control sample), while the highest value of $115 \mu \mathrm{s} / \mathrm{cm}$ was recorded at Ojota South (sample 19) (Table 2). These values represent $93.65 \%$ and $88.5 \%$ respectively, below the $1000 \mu \mathrm{s} / \mathrm{cm}$ WHO threshold. The calculated standard deviation and coefficient of variation of 10.99 and $11.72 \%$ respectively indicated that there are variations in conductivity of sampled water at the various zones; however, the variations are negligible. Figure 3 shows the mean variation of TDS and EC of tap water at the sampled zones.

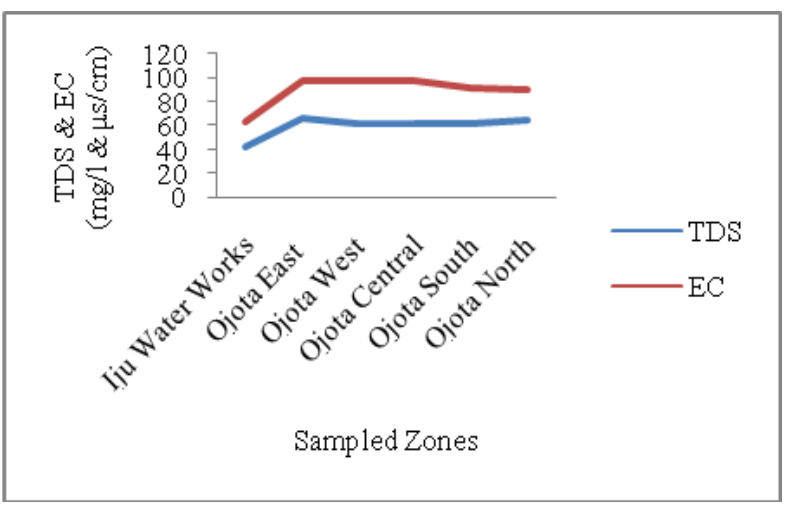

Figure 3. Mean Variation of TDS and EC of Tap Water in the Sampled Zones
The $\mathrm{pH}$ value expresses how acidic or alkaline a body of water is. From the data shown in Table 2, the $\mathrm{pH}$ values range from 6.2 to7.4, with Ojota North (samples 24 and 25 ), respectively having the lowest value of 6.2; while Iju Water Works (control sample) has the highest value of 7.4, which respectively represent $4.62 \%$ below and $13.85 \%$, above the 6.5 minimum acceptable thresholds. In all, 3 (11.54\%) samples have pH values below the WHO 6.5 minimum threshold. Figure 4 shows the mean variation of $\mathrm{pH}$ of tap water at Iju Water Works (control sample) and the sampled zones.

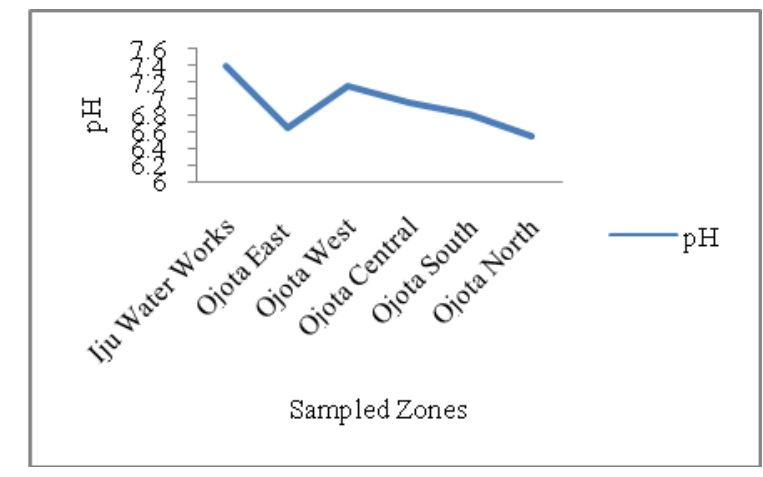

Figure 4. Mean Variation of pH of Tap Water in the Sampled Zones

\subsection{Chemical Parameters}

\subsubsection{Lead, Calcium, Magnesium, Iron, Copper, Cadmium, Zinc, Fluoride, Residual Chlorine, Phosphate and Nitrate}

Heavy metal intrusion into the sources of potable water supply has been of great concern for water experts and health providers all over the world because of the health impacts of their excessive concentration in drinking water sources. For example, studies have shown that excessive concentration of cadmium in drinking water supply could be toxic to the kidney; while lead could cause cancer, interfere with vitamin D metabolism, mental development in infants, toxic to the central and peripheral nervous systems. Also, fluoride could cause fluorosis and skeletal tissue (bones and teeth) morbidity [22]. This explains while considerable attention is paid to their elimination or prevention from drinking water sources.

Table 3 shows the concentration of chemical parameters in the sampled tap water at the various zones and at Iju Water Works (control sample). From the table it was observed that lead concentration ranged from 0 to $0.02 \mathrm{mg} / \mathrm{l}$. Lead was not detected at Iju Water Works (control sample) and 22 (88\%) other samples at the zones. However, $3(12 \%)$ samples show concentration of lead, with sample 7 (Ojota West) having the highest concentration of $0.02 \mathrm{mg} / \mathrm{l}$, which is above the WHO threshold of $0.01 \mathrm{mg} / \mathrm{l}$ in drinking water. Lead is present in tap water to some extent as a result of its dissolution from natural sources but primarily from household plumbing systems in which the pipes solder, fittings, or service connections to homes contain lead. PVC pipes also contain lead compounds that can be leached from them and result in high lead concentration in drinking water [23].

The concentration of calcium in the tap water ranges from 0.30 to $1.50 \mathrm{mg} / \mathrm{l}$, which indicates that all the tap water samples are within the WHO threshold of $200 \mathrm{mg} / \mathrm{l}$. 
Similarly, the concentration of magnesium in all the tap water samples is satisfactory, as it ranges from 0 to 1.06 $\mathrm{mg} / \mathrm{l}$, as against the WHO threshold of $150 \mathrm{mg} / \mathrm{l}$. However, the concentration of iron in the tap water samples is not satisfactory, as 9 samples (36\%) have concentrations above the WHO threshold of $0.3 \mathrm{mg} / \mathrm{l}$. The range of iron in the tap water samples is 0 to $1.50 \mathrm{mg} / \mathrm{l}$. At Iju Water Works (control sample) iron was not detected, which implies that iron was introduced into the water as it is transported through the pipe distribution network by corrosion and oxidation of metal-based materials such as iron to form precipitates in the water [24].

Table 3. Chemical Characteristics of Sampled Tap Water in Ojota

\begin{tabular}{|c|c|c|c|c|c|c|c|c|c|c|c|}
\hline Zone/Sample & $\begin{array}{c}\mathrm{Pb} \\
(\mathrm{mg} / \mathrm{l}) \\
\end{array}$ & $\begin{array}{c}\mathrm{Ca} \\
(\mathrm{mg} / \mathrm{l}) \\
\end{array}$ & $\begin{array}{c}\mathrm{Mg} \\
(\mathrm{mg} / \mathrm{l}) \\
\end{array}$ & $\begin{array}{c}\mathrm{Fe} \\
(\mathrm{mg} / \mathrm{l}) \\
\end{array}$ & $\begin{array}{c}\mathrm{Cu} \\
(\mathrm{mg} / \mathrm{l}) \\
\end{array}$ & $\begin{array}{c}\mathrm{Zn} \\
(\mathrm{mg} / \mathrm{l}) \\
\end{array}$ & $\begin{array}{c}\mathrm{Cd} \\
(\mathrm{mg} / \mathrm{l}) \\
\end{array}$ & $\begin{array}{l}\mathrm{R} . \mathrm{Cl}_{2} \\
(\mathrm{mg} / \mathrm{l}) \\
\end{array}$ & $\begin{array}{c}\mathrm{PO}_{4} \\
(\mathrm{mg} / \mathrm{l}) \\
\end{array}$ & $\begin{array}{c}\mathrm{NO}_{3} \\
(\mathrm{mg} / \mathrm{l}) \\
\end{array}$ & $\begin{array}{c}\mathrm{F} \\
(\mathrm{mg} / \mathrm{l}) \\
\end{array}$ \\
\hline Ojota east 1 & 0 & 1.10 & 1.06 & 0 & 0.10 & 0 & 0 & 0.10 & 0.02 & 0 & 0 \\
\hline Ojota east 2 & 0.01 & 0.50 & 0.60 & 1.0 & 0.10 & 0 & 0 & 0.06 & 0 & 0 & 0.01 \\
\hline Ojota east 3 & 0 & 1.20 & 0.85 & 0.30 & 0.08 & 0 & 0 & 0.03 & 0 & 0 & 0.01 \\
\hline Ojota east 4 & 0 & 0.50 & 0.30 & 0.50 & 0.30 & 0 & 0 & 0.10 & 0 & 0 & 0.01 \\
\hline Ojota east 5 & 0 & 1.30 & 1.02 & 1.50 & 0.20 & 0 & 0 & 0.01 & 0 & 0 & 0 \\
\hline Ojota west 6 & 0 & 0.49 & 0.35 & 0 & 0.04 & 0 & 0 & 0.02 & 0.05 & 0 & 0 \\
\hline Ojota west 7 & 0.02 & 1.50 & 0.90 & 0.80 & 0.10 & 0.01 & 0 & 0.01 & 0 & 0 & 0 \\
\hline Ojota west 8 & 0 & 0.65 & 0.25 & 0.30 & 0.07 & 0 & 0 & 0.05 & 0 & 0 & 0 \\
\hline Ojota west 9 & 0 & 0.60 & 0.50 & 0.02 & 0.15 & 0 & 0 & 0.20 & 0 & 0 & 0.02 \\
\hline Ojota west 10 & 0 & 0.85 & 0.65 & 0.10 & 0.05 & 0 & 0 & 0.08 & 0 & 0 & 0.01 \\
\hline Ojota central 11 & 0 & 1.05 & 0.50 & 0 & 0.10 & 0 & 0 & 0.00 & 0 & 0.05 & 0.02 \\
\hline Ojota central 12 & 0 & 1.20 & 1.00 & 0.40 & 0.06 & 0 & 0 & 0.10 & 0 & 0 & 0.01 \\
\hline Ojota central 13 & 0 & 1.05 & 0.80 & 0.20 & 0.20 & 0 & 0 & 0.20 & 0 & 0 & 0 \\
\hline Ojota central 14 & 0 & 0.62 & 0.50 & 0 & 0 & 0 & 0 & 0.00 & 0 & 0 & 0 \\
\hline Ojota central 15 & 0 & 1.00 & 0.20 & 0.10 & 0.05 & 0 & 0 & 0.25 & 0 & 0 & 0.01 \\
\hline Ojota south 16 & 0 & 1.10 & 0.80 & 0 & 0 & 0 & 0 & 0.10 & 0.01 & 0 & 0.01 \\
\hline Ojota south 17 & 0 & 0.30 & 0.55 & 0.05 & 0.02 & 0.02 & 0 & 0.03 & 0 & 0 & 0 \\
\hline Ojota south 18 & 0 & 0.45 & 0.45 & 0.02 & 0.03 & 0 & 0 & 0.15 & 0 & 0 & 0 \\
\hline Ojota south 19 & 0 & 0.60 & 0.30 & 0.35 & 0.07 & 0 & 0 & 0.10 & 0 & 0 & 0 \\
\hline Ojota south 20 & 0.01 & 1.00 & 0.90 & 0.20 & 0 & 0 & 0 & 0.09 & 0 & 0 & 0 \\
\hline Ojota north 21 & 0 & 1.00 & 0.50 & 0 & 0.05 & 0 & 0 & 0.00 & 0 & 0.01 & 0.01 \\
\hline Ojota north 22 & 0 & 0.75 & 0.70 & 0.20 & 0.10 & 0.01 & 0 & 0.20 & 0 & 0 & 0 \\
\hline Ojota north 23 & 0 & 1.30 & 1.05 & 0.55 & 0.04 & 0 & 0 & 0.25 & 0 & 0.01 & 0.01 \\
\hline Ojota north 24 & 0 & 0.48 & 0.60 & 0.65 & 0.02 & 0 & 0 & 0.20 & 0 & 0 & 0.02 \\
\hline Ojota north 25 & 0 & 1.00 & 0.70 & 1.20 & 0.05 & 0 & 0 & 0.10 & 0 & 0 & 0 \\
\hline $\begin{array}{l}\text { Iju water works } \\
\text { (control ) } 26\end{array}$ & 0 & 0.50 & 0 & 0 & 0 & 0 & 0 & 0.50 & 0 & 0 & 0.03 \\
\hline Range & 0.02 & 1.20 & 1.06 & 1.50 & 0.30 & 0.02 & 0 & 0.50 & 0.05 & 0.05 & 0.03 \\
\hline Mean & 0.00 & 0.85 & 0.62 & 0.32 & 0.08 & 0.00 & 0 & 0.11 & 0.00 & 0.00 & 0.01 \\
\hline Standard deviation & 0.00 & 0.33 & 0.28 & 0.41 & 0.07 & 0.00 & 0 & 0.13 & 0.00 & 0.00 & 0.00 \\
\hline Coefficient of variation (\%) & 0.00 & 38.8 & 45.2 & 128.1 & 87.5 & 0.00 & 0 & 118.2 & 0.00 & 0.00 & 0.00 \\
\hline
\end{tabular}

Source: Author's fieldwork, 2013.

The concentration of copper in the sampled tap water ranges from 0 to $0.30 \mathrm{mg} / \mathrm{l}$. Although all the samples have concentration of copper within the WHO threshold of 0.5 $\mathrm{mg} / \mathrm{l}$, it should be noted however that copper was not detected at Iju Water Works (control sample) but 22 (88\%) samples had concentrations of copper. This shows that copper got into the water in its transportation to the various zones through the pipe distribution network. Zinc was only detected in 3 (12\%) samples, which ranges from 0 to $0.02 \mathrm{mg} / \mathrm{l}$. These values are within the WHO threshold of $3 \mathrm{mg} / \mathrm{l}$ for drinking water. However, cadmium was not detected in any of the water samples. Ageing pipe distribution system could lead to the dissolution of elevated levels of copper, zinc and cadmium into tap water [24].

Chlorine is one of the most widely used disinfectants for the prevention of pathogens in drinking water supply. However, excessive concentration in drinking water supply may constitute serious health challenges. The WHO threshold for residual chlorine in drinking water is 0.2 to $0.5 \mathrm{mg} / \mathrm{l}$. From Table 3 it can be seen that the values of residual chlorine in the sampled water range from 0 to $0.5 \mathrm{mg} / \mathrm{l}$. The highest value of $0.5 \mathrm{mg} / \mathrm{l}$, which is equal to the maximum WHO threshold of $0.5 \mathrm{mg} / \mathrm{l}$, was recorded at Iju Water Works (control sample). However, this value depreciates as the water is transported through the pipe distribution system. For instance, 19 (76\%) samples have concentrations below the minimum threshold of $0.2 \mathrm{mg} / \mathrm{l}$. This reduction may affect the efficacy of chlorine in the prevention of pathogens from the drinking water sources, which may have serious health implications. This explains why total coliform and fecal coliform bacteria counts were detected in some of water samples. The concentration of fluoride in the tap water ranges from 0 to $0.03 \mathrm{mg} / \mathrm{l}$, which are below the WHO threshold of $0.5 \mathrm{mg} / \mathrm{l}$. Fluoride was not detected in 13 (52\%) of the water samples. Both phosphate and nitrate concentrations in the sampled water ranges from 0 to $0.05 \mathrm{mg} / \mathrm{l}$ (Table 3). Similarly, both phosphate and nitrate were only detected in 3 (12\%) samples of tap water, which indicate satisfactory concentration, as the measured values were below the WHO thresholds of $10 \mathrm{mg} / \mathrm{l}$, respectively. Drinking water with nitrate concentration of over $50 \mathrm{mg} / \mathrm{l}$ over a long period could result in cyanosis and asphyxia (blue-baby syndrome) in infants less than 3 months. The mean 
variations of chemical parameters of sampled tap water are presented in Figure 5-Figure 8.

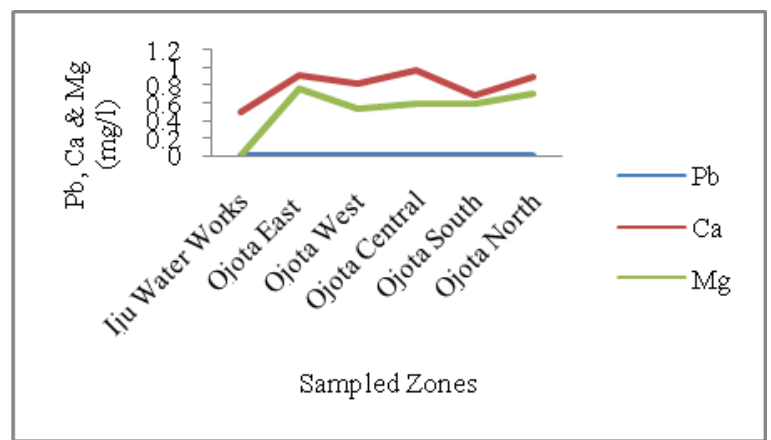

Figure 5. Mean Variation of $\mathrm{Pb}, \mathrm{Ca}$ and $\mathrm{Mg}$ of Tap Water in the Sampled Zones

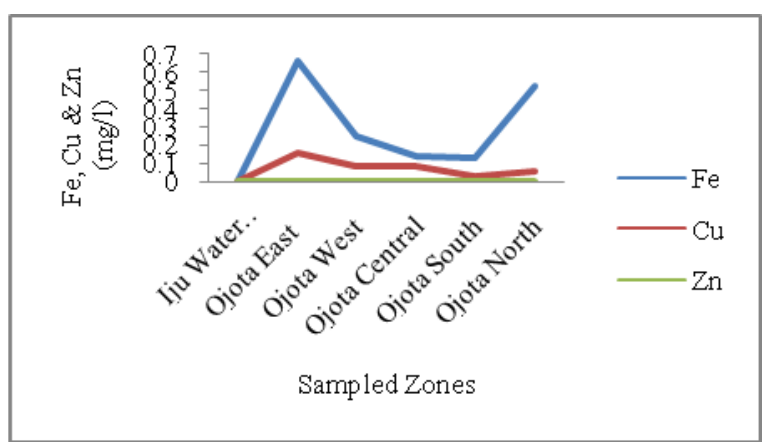

Figure 6. Mean Variation of Fe, Cu \& Zn of Tap Water in the Sampled Zones

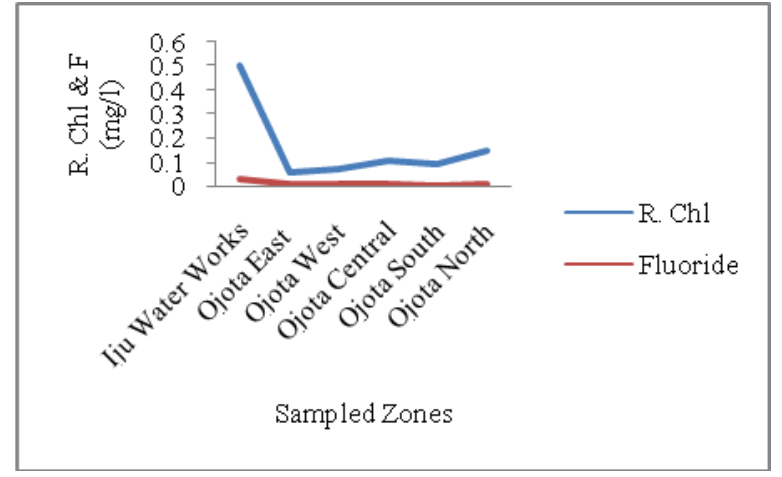

Figure 7. Mean Variation of Residual Chlorine and Fluoride of Tap Water in the Sampled Zones

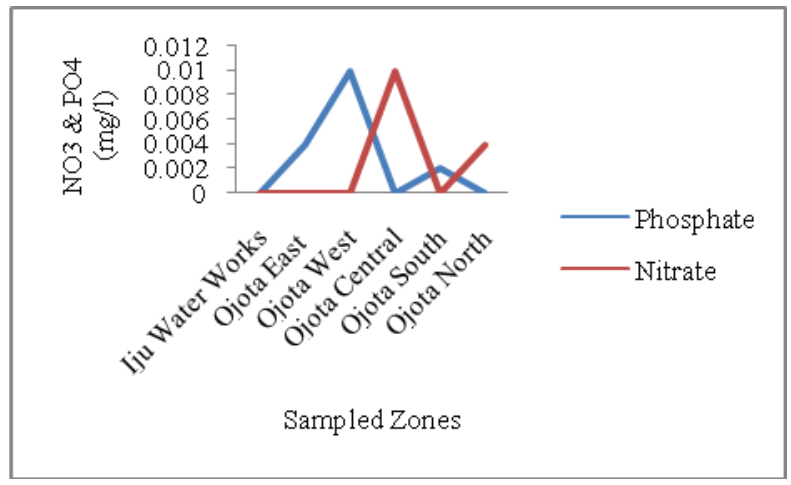

Figure 8. Mean Variation of Phosphate and Nitrate of Tap Water in the Sampled Zones

Table 4. Mean Value of Water Quality Parameters of Iju Water Works and the Sampled Zones

\begin{tabular}{|l|c|c|c|c|c|c|}
\hline Parameter & Iju Water Works & Ojota East & Ojota West & Ojota Central & Ojota South & Ojota North \\
\hline Total coliform counts & 0 & 1 & 2.6 & 1.72 & 0.6 & 0.4 \\
\hline Fecal coliform counts & 0 & 0.24 & 0.56 & 0.24 & 0.08 & 0 \\
\hline Turbidity & 1.07 & 5.99 & 7.1 & 6.51 & 6.33 & 5.83 \\
\hline TSS & 0 & 0.2 & 0.01 & 0.44 & 0.4 & 0.02 \\
\hline TDS & 43 & 65.84 & 61.8 & 61.8 & 61.08 & 64.48 \\
\hline PH & 7.4 & 6.64 & 7.16 & 6.94 & 6.8 & 6.54 \\
\hline Electrical conductivity & 63.5 & 97.1 & 97.68 & 97.42 & 92.4 & 90.34 \\
\hline Color & 4.9 & 8.07 & 9.43 & 8.82 & 9.09 & 6.71 \\
\hline Lead & 0 & 0.002 & 0.004 & 0 & 0.002 & 0 \\
\hline Calcium & 0.5 & 0.92 & 0.82 & 0.98 & 0.69 & 0.91 \\
\hline Magnesium & 0 & 0.77 & 0.53 & 0.6 & 0.6 & 0.71 \\
\hline Iron & 0 & 0.66 & 0.24 & 0.14 & 0.12 & 0.52 \\
\hline Copper & 0 & 0.16 & 0.08 & 0.08 & 0.02 & 0.05 \\
\hline Zinc & 0 & 0 & 0.002 & 0 & 0.004 & 0.002 \\
\hline Cadmium & 0 & 0 & 0 & 0 & 0 & 0 \\
\hline Residual chlorine & 0.5 & 0.06 & 0.07 & 0.11 & 0.08 & 0.05 \\
\hline Phosphate & 0 & 0.004 & 0.01 & 0 & 0.002 & 0 \\
\hline Nitrate & 0 & 0 & 0 & 0.01 & 0 & 0.004 \\
\hline Fluoride & 0.03 & 0.01 & 0.01 & 0.01 & 0 & 0.01 \\
\hline
\end{tabular}

Source: Author's fieldwork, 2013.

A further analysis of the results of the quality parameters concentration in the sampled Tap water was carried out. The analysis revealed that Ojota West Zone was the worst affected. For instance the mean value of total coliform and fecal coliform bacteria counts were 2.6 and $0.56 \mathrm{MPN} / 100 \mathrm{ml}$ respectively (Table 4). Therefore, the incidence of pathogenic bacteria infection would probably be highest in this zone. Similarly, this zone has the highest mean concentration of electrical conductivity $(97.68 \mu \mathrm{s} / \mathrm{cm})$, color $(9.43$ TUC) and lead $(0.004 \mathrm{mg} / \mathrm{l})$ respectively. On the other hand, Ojota East Zone has the highest mean concentration of some of the selected heavy metals such as magnesium $(0.77 \mathrm{mg} / \mathrm{l})$, iron $(0.66 \mathrm{mg} / \mathrm{l})$ and copper $(0.16 \mathrm{mg} / \mathrm{l})$, respectively.

The results of the $\mathrm{T}$-test revealed that there were significant difference in the quality of selected parameters at Iju Water Works and each of the sampled zones as shown in Table 5. These findings revealed that the quality of water that gets to the consumers at the various zones is inadequate for human consumption and could portend great threat to public health. 
Table 5. Calculated T-test Values of Iju Water Works and Each of the Stratified Zones

\begin{tabular}{|c|c|c|c|c|c|c|}
\hline & Parameter & Ojota East & Ojota West & Ojota Central & Ojota South & Ojota North \\
\hline \multirow{3}{*}{ Iju } & Correlation Coefficient & 0.9982 & 0.9971 & 0.9975 & 0.9980 & 0.9980 \\
\hline & T-value & 68.8378 & 53.6583 & 58.1225 & 64.4503 & 64.3004 \\
\hline & Prob(t-value) & 0.0000 & 0.0000 & 0.0000 & 0.0000 & 0.0000 \\
\hline
\end{tabular}

\section{Conclusion}

This study has revealed that the measured values of some of the selected tap water quality parameters varied from Iju Water Works (control sample) to the various sampled zones. For example, the biological parameters of total coliform and fecal coliform bacteria counts show that 8 (30.72\%) and 6 (23.08\%) samples have concentrations above the WHO zero thresholds for total and fecal coliform, respectively. This shows that the biological quality of the tap water has been compromised, and may portend health challenges if consumed without treatment. These pathogenic bacteria found their way into the water source because of leaky pipes, broken valves and laying of pipes on poorly drained gutters. In addition, physical parameters such as turbidity and color show unsatisfactory concentrations in some of the sampled tap water. For example, all the $25(100 \%)$ tap water samples, except the control sample have color concentrations above the WHO 5 unit threshold; while turbidity has 17 (65.38\%) of the samples having concentration above the 5 NTU WHO threshold for drinking water. Similarly, the values of residual chlorine concentration vary from $0.5 \mathrm{mg} / \mathrm{l}$ at $\mathrm{Iju}$ Water Works (control sample) to 0 to 0.25 at the various zones. This shows that the concentration of residual chlorine depreciates as the water travels through the pipe distribution network. This explains the isolation of both total and fecal coliform in some of the sampled tap water.

Although most of the quality parameters are within the WHO thresholds, however, there are noticeable variations of their concentration from Iju Water Works (control sample) to the various zones where the tap water samples were collected. The T-test statistical analysis revealed that there were significant differences between the measured quality parameter values at Iju Water Works with the various stratified zones. This is a clear indication that the integrity of the treated water transported to Ojota through the pipe distribution network has been compromised. Therefore, the safety of the consumption of the tap water may not be guaranteed. It is therefore recommended that the Lagos State Government should undertake a general overhaul and replacement of the dilapidated pipe distribution network in the state to guarantee safe supply of tap water to the populace

\section{References}

[1] World Water Council, "Water supply and sanitation” 2005 [Online] Available:

http://www.worldwatercouncil.org/index.php?id [Accessed 13 November, 2007].

[2] Hunter, P.R; Colford, J.M; Lechevalier, M.W; Binder, S and Berger, P.S, "Water borne diseases, in emerging infectious diseases" (Conference Panel Summaries) 7 (3) p 544 Supplement, June 2001.

[3] WHO/UNICEF, "Water and sanitation report, The Guardian, Monday, December 4, 2006.
[4] Lee, E. J and Schwab, K. J, "Deficiencies in drinking water distribution systems in developing countries”, Journal of Water and Health, 3.2, 109-127. 2005

[5] Lahlou, M. Z, "Water quality in distribution systems". Tech. Brief: A National Drinking Water Clearing House Fact Sheet, 2002.

[6] Frederick, K.D, “America’s water supply: status and prospects for the future”, Consequences, Vol. 1. No. 1, [Online] Available: http://www.gerio.org/CONSEQUENCES/sprint95/water.html. [Accessed 13 October, 2007].

[7] Awwa Research Foundation, "Advancing the science of water: AwwaRF and distribution system water quality" [Online]Available:

http://www.waterrf.org/resources/StateOfTheScienceReports/Distr ibutionSystemWaterQualityResearch.pdf.[ Accessed 5 September, 2013].

[8] APHA, "Standard methods for the examination of water and wastewater. 19th ed. American Public Health Association, Washington, D. C., 1:467. 1998.

[9] Ifenna, I and Chinedu, O, "Heavy metal levels and physicochemical parameters of potable water in Nnewi, Anambra State, Nigeria”, Archives of Applied Science Research, 4 (5): 2094-2097. 2012.

[10] Ohwo, O, "Quality of Water supply from hand-dug wells in Warri-Effurun metropolis Delta State, Nigeria”, Nigeria Geographical Journal, 8 (2): 73-86. 2012.

[11] Basualdo, J., Pezzani, B., De Luca, M., Cordoba, A. \& Apezteguia, M, "Screening the municipal water system of La Plata, Argentina, for human intestinal parasites. Int. J. Hyg. Environ. Health 203(2), 177-182. 2000

[12] Akinyemi, K. O, Oyefolu, A.O.B, Salu, O.B, Adewale, O.A and Fasure, A.K, "Bacteria pathogens associated with tap and well waters in Lagos, Nigeria”. East and Central African Journal of Surgery, 11(1) 110-117. 2006.

[13] Gaytan, M., Castro, T., Bonilla, P., Lugo, A. \& Vilaclara, G, "Preliminary study of selected drinking water samples in Mexico City”, Rev. Int. Contamin. Ambient 13(2), 73-78. 1997.

[14] Agard, L., Alexander, C., Green, S., Jackson, M., Patel, S. \& Adesiyun, A, "Microbial quality of water supply to an urban community in Trinidad,” J. Food Prot. 65(8), 1297-1303. 2002.

[15] Mermin, J. H., Villar, R., Carpenter, J., Roberts, L., Samaridden, A., Gasanova, L., Lomakina, S., Bopp, C., Hutwagner, L., Mead, P., Ross, B. \& Mintz, E. D, “A massive epidemic of multidrugresistant typhoid fever in Tajikistan associated with consumption of municipal water,” J. Infect. Dis. 179(6), 1416-1422. 1999.

[16] Semenza, J. C., Roberts, L., Henderson, A., Bogan, J. \& Rubin, C. $\mathrm{H}$, "Water distribution system and diarrheal disease transmission: A case study in Uzbekistan,” Am. J. Trop. Med.Hyg. 59(6), 941946. 1998.

[17] US Environmental Protection Agency, "National primary drinking water standards,” Environmental Protection Agency, Washington, DC. 2003.

[18] Hammer, M. J. \& Hammer, M. J. J, Water and wastewater technology, 4th edn. Prentice-Hall, Upper Saddle River, New Jersey. 2001.

[19] Juhna, T. \& Klavins, M, "Water-quality changes in Latvia and Riga 1980-2000: possibilities and problems,” Ambio 30(4-5), 306314. 2001.

[20] Besner, M. C., Gauthier, V., Servais, P. \& Camper, A, "Explaining the Occurrence of Coliforms in Distribution Systems," J. Am. Wat. Wks Assoc. 94(8), 95-109. 2002.

[21] Herrick, D, “Cross-connections and backflow,” Wat. Well J. 51(5), 67-70. 1997.

[22] Standards Organization of Nigeria, Nigeria standard for drinking water quality, ICS13.060.20: Nigeria Industrial Standard Manual, NIS 554: 2007.

[23] Kumar, M. and Puri, A, "A review of permissible limits of drinking water,” Indian J Occup Environ Med 16(1) 40-44. 2012.

[24] Wagner, I, International report: internal corrosion of pipes in public water distribution networks. Wat. Suppl. 12(1/2), IR7-1IR7-5. 1994. 